ENCYCLOPEEDIE Encyclopédie berbère

BERBERE

18 | 1997

18 | Escargotière - Figuig

\title{
Feratus Mons
}

(voir Feratenses)

\section{OpenEdition}

Journals

Édition électronique

URL : http://journals.openedition.org/encyclopedieberbere/2034

DOI : 10.4000/encyclopedieberbere.2034

ISSN : 2262-7197

Éditeur

Peeters Publishers

Édition imprimée

Date de publication : 1 août 1997

Pagination : 2766

ISBN : 2-85744-948-8

ISSN : 1015-7344

\section{Référence électronique}

"Feratus Mons », Encyclopédie berbère [En ligne], 18 | 1997, document F17, mis en ligne le 01 juin 2011, consulté le 25 septembre 2020. URL : http://journals.openedition.org/encyclopedieberbere/ 2034 ; DOI : https://doi.org/10.4000/encyclopedieberbere.2034

Ce document a été généré automatiquement le 25 septembre 2020.

(c) Tous droits réservés 


\section{Feratus Mons}

(voir Feratenses) 